\title{
Molecular data confirm the presence of Nycticebus bengalensis on Langkawi Island, Malaysia
}

\author{
BADRUL MUNIR MD-ZAIN ${ }^{1, \bullet}$, KHAIRUL SYA'ADAH MOHHOYUA ${ }^{1}$, NOR RAHMAN AIFAT ${ }^{1}$, \\ EHWAN NGADI ${ }^{1}$, NORSHAQINAH AYOB ${ }^{1}$, JEFFRINE JAPNING ROVIE-RYAN ${ }^{2}$, AHMAD AMPENG ${ }^{3}$, \\ ABD RAHMAN MOHD-RIDWAN ${ }^{1,4}$, MARY E BLAIR ${ }^{5}$, MUHAMMAD ABU BAKAR ABDUL-LATIFF ${ }^{6}$ \\ ${ }^{1}$ School of Environmental and Natural Resource Sciences, Faculty of Science and Technology, Universiti Kebangsaan Malaysia. \\ 43600, Bangi, Selangor, Malaysia. Tel.: +60-389-213200, `email: abgbadd@ukm.edu.my, abgbadd1966@yahoo.com \\ ${ }^{2}$ Department of Wildlife and National Park (DWNP) Peninsular Malaysia, Km 10 Jalan Cheras, 56100 Kuala Lumpur, Malaysia \\ ${ }^{3}$ Sarawak Forest Department, Wisma Sumber Alam Jalan Stadium, 93660 Petra Jaya, Kuching, Sarawak, Malaysia \\ ${ }^{4}$ Centre for Pre-University Studies, Universiti Malaysia Sarawak,94300 Kota Samarahan, Sarawak, Malaysia \\ ${ }^{5}$ Center for Biodiversity and Conservation, American Museum of Natural History, Central Park West \& 79th St, New York, NY 10024, United States \\ ${ }^{6}$ Centre of Research for Sustainable Uses of Natural Resources (CoR-SUNR), Faculty of Applied Sciences and Technology, Universiti Tun Hussein Onn \\ Malaysia (Pagoh Campus). 84000, Muar, Johor, Malaysia
}

Manuscript received: 23 February 2019. Revision accepted: 24 March 2019.

\begin{abstract}
Md-Zain BM, Mohhoyua KS, Aifat NR, Ngadi E, Ayob N, Rovie-Ryan JJ, Ampeng A, Mohd-Ridwan AR, Blair ME, Abdul-Latiff MAB. 2019. Molecular data confirm the presence of Nycticebus bengalensis on Langkawi Island, Malaysia. Biodiversitas 20: 11151120. Recent taxonomic reviews have stated the possibility of Bengal Slow Loris (Nycticebus bengalensis) presence in the Northern part of the Malay Peninsula. This study aims to confirm the presence of the Bengal Slow Loris in Malaysia by sequencing the mitochondrial COI gene from samples collected from Langkawi Island, Peninsular Malaysia, and Borneo. Phylogenetic analyses produced tree topologies that support the grouping of slow loris samples by their localities. The tree topologies further show that slow loris samples from Sarawak and Peninsular Malaysia form two distinct clades. The clade from Peninsular Malaysia was divided into two subclades, Langkawi and Selangor. The Langkawi slow loris subclade includes sequences from GenBank representing $N$. bengalensis, supported by a high bootstrap value. This mitochondrial DNA finding has a significant contribution to indicate the presence of the Bengal Slow Loris in Malaysia.
\end{abstract}

Keywords: Biogeography, Malaysian primates, Nycticebus bengalensis, Nycticebus coucang, phylogeny, slow loris

\section{INTRODUCTION}

The slow loris (Genus Nycticebus, family Lorisidae) is a nocturnal primate found in South and Southeast Asian regions (Roos et al. 2014). Species distributions range from eastern India to Indochina and southern China south to the Malay Peninsula and Java, Borneo to the western Philippines (Groves 2001; Brandon-Jones et al. 2004). There are eight species currently recognized under this genus Nycticebus coucang, Nycticebus javanicus, Nycticebus pygmaeus, Nycticebus bengalensis, Nycticebus menagensis, Nycticebus kayan, Nycticebus bancanus and Nycticebus borneanus (Munds et al. 2013; Nekaris and Starr 2015). N. bengalensis has the largest range of any species in the genus because it is found in Myanmar, Cambodia, southern China, northeast India, Laos, Thailand, Vietnam and Bangladesh (Brandon-Jones et al. 2004; Roos et al. 2014).

Most Nycticebus classifications were based on morphological data while few molecular studies have been performed (Chen et al. 2006; Cao et al. 2017). Similar morphological characteristics between species make the identification process difficult at the species or subspecies level (Blair et al. 2011). Previous molecular studies were conducted by Chen et al. (2006) and Md-Zain et al. (2009) to study the taxonomy of Nycticebus. Using the mitochondrial gene Cytochrome $b$ (Cyt $b$ ), Md-Zain et al. (2009) showed separation between samples from Peninsular Malaysia and Borneo that were later considered as different species (Roos et al. 2014). In addition, Chen et al. (2006) found that $N$. c. coucang and N. bengalensis could not be distinguished, probably due to the limited geographic sampling of this study or misidentification of specimens. While eight species are currently recognized in the genus (Nekaris \& Starr 2015), many more molecular systematic studies need to be carried out to improve our understanding of Nycticebus genetic identity and current distribution.

Previously, only $N$. coucang has been described as distributed in the Malay Peninsula, with several subspecies (Brandon-Jones et al. 2004). Recently, Rovie-Ryan et al. (2018) rediscovered $N$. c. insularis in Tioman Island using two mitochondrial loci, the Cyt $b$ and D-loop region. The presence of $N$. bengalensis has been hypothesized in the Northern part of the Malay Peninsula; however, no scientific evidence is available to confirm the presence. This paper presents the first-ever molecular scientific study to confirm the presence of $N$. bengalensis in Malaysia using the Cytochrome Oxidase I (COI) mitochondrial region as a candidate locus. The COI gene has been widely used in systematic, population and phylogeography studies in primates (Abdul-Latiff et al. 2017) and other mammals 
(Bakar et al. 2017, 2018; Syed-Shabthar et al. 2013; Rosli et al. 2011). The COI gene has also been selected as a good candidate marker for DNA barcoding for species identification and wildlife forensic applications (Md-Zain et al. 2018a,b; Mohd-Yusof et al. 2018).

\section{MATERIALS AND METHODS}

\section{DNA extraction, Polymerase Chain Reaction (PCR) and sequencing}

Fecal, tissue and FTA cards of Nycticebus were collected from Sarawak, Selangor and Langkawi Island comprising a total of 10 genetic samples (Table 1). Tissue samples were collected from road kill specimens while other genetic samples were provided by the Department of Wildlife and National Park (PERHILITAN) Peninsular Malaysia and Sarawak Forestry Department with special research permit by Ministry of Natural Resources and Environment (NRE 600-2/2/21 Jilid 6 (35). In this study, three different extraction kits were used: the innuPREP Stool DNA Kit (Analytik Jena, Germany) for fecal samples, innuPREP DNA Mini Kit (Analytik Jena, Germany) for tissue samples and innuPREP Forensic Kit (Analytik Jena, Germany) for FTA cards. DNA was extracted from 0.5-1.0g of fecal samples (Abdul-Latiff et al. 2014a, b), 0.02g of tissue samples (Aifat et al. 2016a) and a few punches of FTA cards following the manufacturer's protocol.

We used representatives of $N$. menagensis, $N$. bengalensis and $N$. pygmaeus sequences to conduct a comparative analysis of genus Nycticebus. Reference sequences for these taxa are available in GenBank for the Cytochrome Oxidase I (COI) region. Table 2 shows a primer sequence for the COI region designed specifically for Nycticebus (Blair, Unpublished) that was used to amplify all the in-hand genetic samples.
A total of $\sim 400 \mathrm{bp}$ fragment of the mitochondrial COI region were successfully amplified through polymerase chain reaction (PCR) using Mastermx MyTaq Red Mix (Bioline) and Mastercycler Nexus (Eppendorf North America, Inc.). The PCR involved a three-step PCR protocol following Abdul-Latiff et al. (2017) (Table 3 and Table 4). Purification was done by using doublePURE kit, and the samples were subsequently sent to Apical Scientific Sdn Bhd (Malaysia) for sequencing purposes.

Table 2. Primer sequence of COI region

\begin{tabular}{lll}
\hline Primer & Sequence (5'-3') & Reference \\
\hline \multirow{2}{*}{ 5288F } & CACCTCGAGGCCTGGTAAAAA & Blair, \\
& GGG & Unpublished \\
5704R & GCCGGCTCCGGCCTCAACTA & Blair, \\
& & Unpublished \\
\hline
\end{tabular}

Table 3. PCR cocktail involved in DNA amplification

\begin{tabular}{lcc}
\hline Components & Final concentration & Volume $(\mu \mathbf{L})$ \\
\hline My Taq Red Mix & & 12.5 \\
Forward primer & $20 \mu \mathrm{mol}$ & 1.0 \\
Reverse primer & $20 \mu \mathrm{mol}$ & 1.0 \\
DNA template & & 3.0 \\
$\mathrm{ddH}_{2} \mathrm{O}$ & & 7.5 \\
Total & & 25 \\
\hline
\end{tabular}

Table 4. PCR profile

\begin{tabular}{lccc}
\hline \multicolumn{1}{c}{ Parameter } & $\begin{array}{c}\text { Temperature } \\
\left({ }^{\circ} \mathbf{C}\right)\end{array}$ & Time & Cycle \\
\hline Pre-denaturation & 95 & 3 minutes & 1 \\
Denaturation & 95 & 15 seconds & 30 \\
Annealing & 60.8 & 30 seconds & 30 \\
Elongation & 72 & 10 seconds & 30 \\
Final elongation & 72 & 10 minutes & 1 \\
\hline
\end{tabular}

Table 1. The list of samples used in this study

\begin{tabular}{llll}
\hline Sample name & Types of samples & Locality & GenBank accession no. \\
\hline LANGKAWI 1 & FTA card & Langkawi Island & \\
LANGKAWI 2 & Tissue & Langkawi Island & \\
LANGKAWI 3 & Tissue & Langkawi Island & \\
$N$. coucang A024 & FTA card & Selangor & \\
$N$. coucang ZZ098 & FTA card & Selangor & \\
$N$. coucang CS & FTA card & Selangor & \\
$N$. coucang C4 & FTA card & Selangor & \\
$N$. coucang C7 & FTA card & Selangor & \\
$N$. menagensis BMNCQ 21 & FTA card & Lundu, Sarawak & \\
$N$. menagensis & Fecal & & \\
$N$. bengalensis & GenBank & & GQ259901 (Somura et al. 2012) \\
$N$. bengalensis & GenBank & & KC977312 (Somura et al. 2013) \\
$N$. bengalensis & GenBank & & KC757405 (Finstermeier et al. 2013) \\
$N$. pygmaeus & GenBank & & NC033381 (Ni et al. 2016) \\
$N$. pygmaeus & GenBank & & KX397281 (Ni et al. 2016) \\
$N$. pygmaeus & GenBank & & GQ259902 (Somura et al. 2012) \\
Loris tardigradus & GenBank & & NC012763 (Matsui et al. 2009) \\
\hline
\end{tabular}




\section{Sequence and phylogenetic analysis}

Bioedit Sequence Alignment Editor was used to edit the obtained raw sequences and blasted through GenBank BLASTn for sequence similarity searches analysis (Aifat et al. 2016b; Abdul-Latiff et al. 2019). All the sequences were aligned using MEGA7 ClustalW multiple alignments (Kumar et al. 2016). Two levels of analysis were performed namely sequence and phylogenetic analysis. MEGA7 and PAUP 4.0B10 (Swofford 2002) software were used in sequence and phylogenetic analyses to reconstruct phylogenetic trees and genetic distances. Phylogenetic trees were constructed using character-based (maximum parsimony (MP) and distance-based (neighbor-joining (NJ) methods. The tree bisection and reconnection (TBR) algorithms were used for the MP tree. The heuristic searching method and 1000 random stepwise additions were applied to find the best tree through the application of the $50 \%$ consensus majority rule. All the trees constructed underwent 1000 bootstrap replications to obtain the bootstrap confidence level. The Kimura 2-parameter model was used in $\mathrm{NJ}$ tree reconstructions tested with a bootstrap value of 1000 .

\section{RESULTS AND DISCUSSION}

\section{COI sequence analysis}

Sequence analysis

A total of $404 \mathrm{bp}$ of the COI gene for ten slow loris samples were successfully sequenced and used in the final alignment. The sequences obtained were blasted against NCBI's GenBank database for species identification (Table 5). Out of the total $404 \mathrm{bp}, 272(67.33 \%)$ are conserved sites, $66(16.3 \%)$ variable sites, $54(13.36 \%)$ parsimony uninformative sites and $12(2.97 \%)$ parsimony informative sites. The mean nucleotide frequencies were, for thymine $(\mathrm{T})=30.5 \%$, cytosine $(\mathrm{C})=21.6 \%$, adenosine $(\mathrm{A})=$ $26.6 \%$, and guanine $(\mathrm{G})=19.6 \%$. The observed genetic distance ranged from $0-21.3 \%$ (Table 6). The highest genetic distance value is $21.3 \%$, between $N$. pygmaeus and the outgroup (Loris tardigradus). Samples from Selangor showed the lowest genetic distances (A024, CS, ZZ098, $\mathrm{C} 4$, and $\mathrm{C} 7$ ) with $0.0 \%$ indicating that the individuals within this population are genetically the same.

\section{Phylogenetic trees}

Information gained from the reconstruction of the most parsimonious tree (length: 86) using the MP method are shown with a consistency index (0.7959), retention index (0.8718) and composite index (0.6939). NJ and MP trees produced two major groups separating slow loris samples from Sarawak (N. menagensis and BMNCQ21) from those from Peninsular Malaysia with more than a 55\% confidence value (Figure 1 and Figure 2). Support for tree topologies was analyzed through NJ bootstrap estimates with 1000 replicates. The trees grouped all the individuals from the Selangor in the same clade with a bootstrap confidence value of more than 60\% (C7, C4, ZZ098, A024, and CS). Individuals from Langkawi and Thailand $(N$. bengalensis) are grouped in the same clade suggesting that the individuals are the same species, consistent with our GenBank BLAST analysis. The separation between $N$. bengalensis and $N$. coucang clades was supported by high bootstrap value $(99 \%)$.

The phylogenetic clade formation shown in this study is consistent with previous studies conducted on the molecular phylogeny of Nycticebus. While this study did not employ the real genetic samples of $N$. pygmaeus as others have done (Chen et al. 2006; Somura et al. 2012), we managed to produce the same tree topology in which $N$. pygmaeus diverged earlier as compared to $N$. bengalensis and $N$. coucang (Rovie-Ryan et al. 2018). We also find support for following suggestions by Rovie-Ryan et al. (2018) to utilize samples from known and credible localities only, thus increasing the confidence level of our analysis confirming the presence of $N$. bengalensis in Langkawi Island. We are also aware of the notion put forth by Groves (2001) that there is a possibility of a hybridization event occurring between $N$. coucang and $N$. bengalensis near the Isthmus of $\mathrm{Kra}$; however, our phylogenetic analysis shows a clear distinction between the species. Although our geographic sampling is the most thorough to date for slow lorises in Malaysia, hybridization could still be supported by a higher resolution of geographic sampling in the Isthmus.

Table 5. The results of the species confirmation using the GenBank BLAST

\begin{tabular}{lccccc}
\hline Sample & Marker & E & $\begin{array}{c}\text { \% Identity } \\
\text { percentage } \mathbf{( \% )}\end{array}$ & Species & $\begin{array}{l}\text { GenBank } \\
\text { Accession No. }\end{array}$ \\
\hline A024 & COI & 0 & 99 & coucang & AJ309867.1 \\
CS & COI & 0 & 99 & N. coucang & AJ309867.1 \\
C4 & COI & 0 & 99 & N. coucang & AJ309867.1 \\
C7 & COI & 0 & 99 & N. coucang & AJ309867.1 \\
SELANGOR & COI & 0 & 99 & N. coucang & AJ309867.1 \\
BMNCQ 20 & COI & 0 & 99 & N. coucang & AJ309867.1 \\
Langkawi 1 & COI & 0 & 100 & N. bengalensis & KC977312.1 \\
Langkawi 2 & COI & 0 & 100 & N. bengalensis & KY436589.1 \\
Langkawi 3 & COI & 0 & 100 & N. bengalensis & KY436589.1 \\
ZZ098 & COI & 0 & 99 & N. coucang & AJ3098667.1 \\
\hline
\end{tabular}




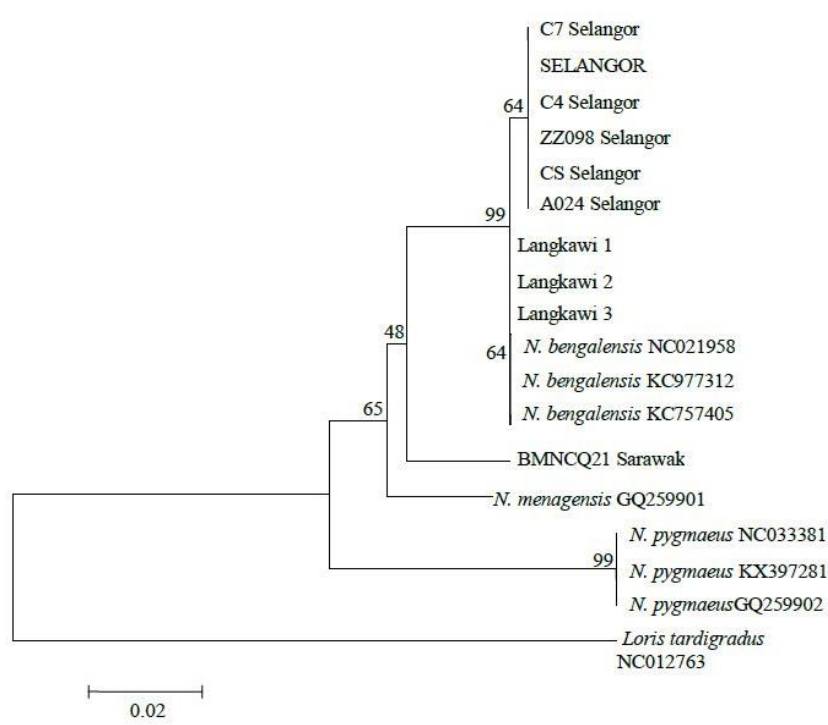

Figure 1. Neighbor-Joining (NJ) tree of slow loris samples based on $404 \mathrm{bp}$ of the mtDNA COI gene. Values shown next to branches are the bootstrap estimates with 1000 replicates

The argument that $N$. bengalensis might be present in northern Peninsular Malaysia is not new (Groves 2001; Roos et al. 2014). In that region, the southernmost confirmed distribution as acknowledged by Streicher et al. (2008) is near southwestern Satun, Thailand and the direct distance from this area to Langkawi Island is less than 30 KM (by sea). We may also consider that $N$. bengalensis might be present in northern Perlis, surviving in the remnants of Perlis State Park, the distance between these two areas is less than $40 \mathrm{KM}$. Thus, we hypothesize that the populations of $N$. bengalensis on Langkawi Island are natural populations not recorded by previous studies. This is not surprising as this understudied group of primates has received less attention as compared to other species (Blair et al. 2011), further supported by the rediscovery of $N$. $c$. insularis in Tioman Island, Malaysia by Rovie-Ryan et al. (2018). This attention-deprived situation can largely be attributed to two factors as highlighted by Nekaris et al. (2008): Nycticebus species are abundant in some areas but genuinely rare in others, or it takes time for surveyors to learn how to survey nocturnal lorises accurately, or alternatively, it takes time for the lorises to adapt to the presence of surveyors.

The findings of this research have significant conservation implications for the slow loris in Malaysia, in addition to significant findings for slow loris biogeography. Slow lorises are among the most commonly traded protected primates in marketplaces across their ranges (Nekaris \& Nijman 2007) and have long been exploited in traditional medicines, with reports dating back to 1900 (Ridley 1900). Throughout Asian countries, due to superstitious belief, slow lorises are considered to cure up to 100 ailments; thus they are heavily hunted and killed for their perceived medicinal value (Starr et al. 2010; Thach et al. 2018). The Department of Wildlife and National Parks Malaysia (PERHILITAN) are actively combatting slow

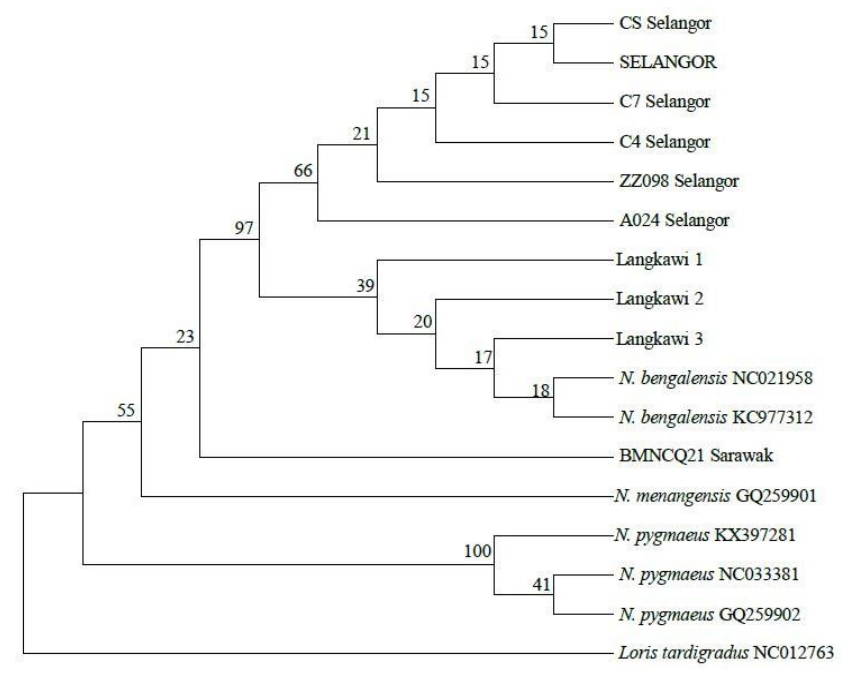

Figure 2. Maximum Parsimony (MP) tree of slow loris samples based on $404 \mathrm{bp}$ of the mtDNA COI gene. Values shown above the branches are bootstrap estimates with 1000 replicates

loris pet trade issues, and all confiscated animals will be temporarily placed in the National Wildlife Rescue Centre (NWRC) for assessment before releasing them to their natural environment. Thus, through this research, PERHILITAN will now be able to safeguard the unique gene pool of $N$. bengalensis in Langkawi Island and $N$. coucang in mainland Peninsular Malaysia by using molecular and analysis to identify the confiscated slow lorises prior to the release of healthy individuals. NurSyuhada et al. (2016) have also reported a translocation of $N$. coucang from Hulu Terengganu, Terengganu Malaysia due to Hulu Terengganu Hydroelectric Project in the area. Findings in this research should well be incorporated to any management and conservation action plan in Malaysia to avoid translocating $N$. coucang and $N$. bengalensis to the wrong habitat by assuming all slow lorises in Malaysia belong to $N$. coucang.

MtDNA data has successfully identified the clear distinction of $N$. bengalensis from Langkawi Island as compared to $N$. coucang only by utilizing the COI region. Although this region is conserved (Md-Zain et al. 2018a), it has proven to be effective locus to identify different species of slow loris. Rovie-Ryan et al. (2018) reported an unresolved topology of a phylogenetic tree of Nycticebus based on the Cytochrome $b$ region, although the data are not shown. For future study, we suggest the use of other loci which have been proven to resolve species-level phylogeny in primates such as the D-loop (Abdul-Latiff et al. 2014b), ND4 (Takacs et al. 2005) and also a reattempt of Cyt $b$ using different, species-specific primers as compared to Rovie-Ryan et al. (2018), as the vast data of Cyt $b$ on GenBank is useful for comparative analysis purposes, especially in biogeography (Abdul-Latiff et al. 2017; Abdul-Latiff et al. 2019). Future hybrid confirmation will also need to be investigated between $N$. coucang and N. bengalensis. 
Table 6. Genetic distance percentage (\%) between individual based on COI sequence

\begin{tabular}{|c|c|c|c|c|c|c|c|c|c|c|c|c|c|c|c|c|c|c|}
\hline & Samples & 1 & 2 & 3 & 4 & 5 & 6 & 7 & 8 & 9 & 10 & 11 & 12 & 13 & 14 & 15 & 16 & 1718 \\
\hline 1 & N. coucang A024_Selangor & & & & & & & & & & & & & & & & & \\
\hline 2 & N. coucang CS_Selangor & 0.0 & & & & & & & & & & & & & & & & \\
\hline 3 & N. coucang ZZ098_Selangor & 0.0 & 0.0 & & & & & & & & & & & & & & & \\
\hline 4 & N. coucang C4_Selangor & 0.0 & 0.0 & 0.0 & & & & & & & & & & & & & & \\
\hline 5 & N. coucang C7_Selangor & 0.0 & 0.0 & 0.0 & 0.0 & & & & & & & & & & & & & \\
\hline 6 & N. coucang SELANGOR & 0.0 & 0.0 & 0.0 & 0.0 & 0.0 & & & & & & & & & & & & \\
\hline 7 & Langkawi 1 & 0.3 & 0.3 & 0.3 & 0.3 & 0.3 & 0.3 & & & & & & & & & & & \\
\hline 8 & Langkawi 2 & 0.3 & 0.3 & 0.3 & 0.3 & 0.3 & 0.3 & 0.0 & & & & & & & & & & \\
\hline 9 & Langkawi 3 & 0.3 & 0.3 & 0.3 & 0.3 & 0.3 & 0.3 & 0.0 & 0.0 & & & & & & & & & \\
\hline 10 & N. bengalensis $\mathrm{NC} 021958$ & 0.3 & 0.3 & 0.3 & 0.3 & 0.3 & 0.3 & 0.0 & 0.0 & 0.0 & & & & & & & & \\
\hline 11 & N. bengalensis KC977312 & 0.3 & 0.3 & 0.3 & 0.3 & 0.3 & 0.3 & 0.0 & 0.0 & 0.0 & 0.0 & & & & & & & \\
\hline 12 & N. bengalensis KC757405 & 0.3 & 0.3 & 0.3 & 0.3 & 0.3 & 0.3 & 0.0 & 0.0 & 0.0 & 0.0 & 0.0 & & & & & & \\
\hline 13 & N. pygmaeus NC033381 & 8.7 & 8.7 & 8.7 & 8.7 & 8.7 & 8.7 & 8.3 & 8.3 & 8.3 & 8.3 & 8.3 & 8.3 & & & & & \\
\hline 14 & N. pygmaeus KX397281 & 8.7 & 8.7 & 8.7 & 8.7 & 8.7 & 8.7 & 8.3 & 8.3 & 8.3 & 8.3 & 8.3 & 8.3 & 0.0 & & & & \\
\hline 15 & N. pygmaeus GQ259902 & 8.7 & 8.7 & 8.7 & 8.7 & 8.7 & 8.7 & 8.3 & 8.3 & 8.3 & 8.3 & 8.3 & 8.3 & 0.0 & 0.0 & & & \\
\hline 16 & N. menagensis & 4.3 & 4.3 & 4.3 & 4.3 & 4.3 & 4.3 & 4.0 & 4.0 & 4.0 & 4.0 & 4.0 & 4.0 & 7.5 & 7.5 & 7.5 & & \\
\hline 17 & BMNCQ21 Sarawak & 4.0 & 4.0 & 4.0 & 4.0 & 4.0 & 4.0 & 3.6 & 3.6 & 3.6 & 3.6 & 3.6 & 3.6 & 7.6 & 7.6 & 7.6 & 4.3 & \\
\hline 18 & LORIS & 19.5 & 19.5 & 19.5 & 19.5 & 19.5 & 19.5 & 19.5 & 19.5 & 19.5 & 19.5 & 19.5 & 19.5 & 21.3 & 21.3 & 21.3 & 19.5 & 19.5 \\
\hline
\end{tabular}

\section{ACKNOWLEDGEMENTS}

We are deeply indebted to Langkawi Research Center (Universiti Kebangsaan Malaysia) for assistance collecting genetic samples. We thank the Department of Wildlife and National Park (PERHILITAN) Peninsular Malaysia and Ministry of Natural Resources and Environment (NRE) for special research permit (NRE 600-2/2/21 Jilid 6 (35). The authors acknowledge Universiti Kebangsaan Malaysia for providing necessary funding, facilities, and assistance. This research was supported by Universiti Kebangsaan Malaysia Grants AP-2015-004, and UKM-GUP-2017-087. Co-author Blair was supported by the U.S. National Science Foundation (CHE-1313908), the Margot Marsh Biodiversity Foundation and the Eppley Foundation for Research.

\section{REFERENCES}

Abdul-Latiff MAB, Ruslin F, Vun VF, Mohd-Hashim A, Rovie-Ryan JJ, Abdul-Patah P, Lakim M, Roos C, Yaakop S, Md-Zain BM. 2014a. Phylogenetic relationships of Malaysia's long-tailed macaques, Macaca fascicularis, based on cytochrome b sequences. ZooKeys 407: 121-139.

Abdul-Latiff MAB, Ruslin F, Faiq H, Hairul MS, Rovie-Ryan JJ, AbdulPatah P, Yaakop S, Md-Zain BM. 2014b. Continental monophyly and molecular divergence of Peninsular Malaysia's Macaca fascicularis fascicularis. Biomed Res Intl 2014: 897682.

Abdul-Latiff MAB, Aifat NR, Yaakop S, Md-Zain BM. 2017. A noninvasive molecular approach: exploiting species-locus-specific PCR primers in defeating numts and DNA cross-contamination of Cercopithecidae. J Anim Plant Sci 27: 1015-1023.

Abdul-Latiff MAB, Baharuddin H, Abdul-Patah P, Md-Zain BM. 2019. Is Malaysia's banded langur, Presbytis femoralis femoralis, actually Presbytis neglectus neglectus? Taxonomic revision with new insights on the radiation history of the Presbytis species group in Southeast Asia. Primates 60: 63-79.

Aifat NR, Yaakop S, Md-Zain BM. 2016a. Optimization of partial Cyt $b$ gene sequence from selected ancient Presbytis museum skin specimens. Malays Appl Biol 45: 93-96.
Aifat NR, Yaakop S, Md-Zain BM. 2016b. Ancient DNA analyses of museum specimens from selected Presbytis (Primate: Colobinae) based on partial Cyt $b$ sequences. AIP Conf Proc 1784: 060024. DOI: 10.1063/1.4966862.

Bakar MAAA, Rovie-Ryan JJ, Ampeng A, Yaakop S, Nor SM, Md-Zain BM. 2017. Optimisation of polymerase chain reaction conditions to amplify D-loop region in the Malaysian mousedeer genomic DNA. Malays Appl Biol 46: 63-71.

Bakar MAAA, Rovie-Ryan JJ, Ampeng A, Yaakop S, Nor SM, Md-Zain BM. 2018. Genetic distance of Malaysian mousedeer based on mitochondrial DNA cytochrome oxidase I (COI) and D-loop region sequences. AIP Conf Proc 1940: 020035. DOI: 10.1063/1.5027950.

Blair ME, Sterling EJ, Hurley MM. 2011. Taxonomy and conservation of Vietnam's primates: a review. Amer J Primatol 73: 1093-1106.

Brandon-Jones D, Eudey AA, Geissmann T, Groves CP, Melnick DJ, Morales JC, Shekelle M, Stewart CB. (2004). Asian primate classification. Intl J Primatol 25: 97-164

Cao G, Blair ME, Le M, Nekaris KAI. 2017. Conservation of the Slow Loris, Nycticebus spp., at the genetic level: phylogenetics, phylogeography and population genetics. Folia Primatologica 88: 170.

Chen JH, Pan D, Groves CP, Wang YX, Narushima E, Fitch-Snyder H, Crow P, Thanh VN, Ryder O, Zhang HW, Fu YX, Zhang YP. 2006. Molecular phylogeny of Nycticebus inferred from mitochondrial genes. Intl J Primatol 27: 1187-1200.

Finstermeier K, Zinner D, Brameier M, Meyer M, Kreuz E, Hofreiter M, Roos C. 2013. A mitogenomic phylogeny of living primates. PLoS One 8 (7): e69504. DOI: 10.1371/journal.pone.0069504

Groves CP. 2001. Primate Taxonomy. Smithsonian Institute Press, Washington DC.

Kumar S, Stecher G, Tamura K. 2016. MEGA7: Molecular evolutionary genetics analysis version 7.0 for bigger datasets. Mol Biol Evol 33: 1870-1874.

Matsui A, Rakotondraparany F, Munechika I, Hasegawa M, Horai S. 2009. Molecular phylogeny and evolution of prosimians based on complete sequences of mitochondrial DNA. Gene 441: 53-66.

Md-Zain BM, Abd-Pateh N, Ang KC, Vun VF, Zainal ZZ, Lakim M, Ampeng A, Shukor MN, Mahani MC. 2009. Molecular systematics of Nycticebus coucang and its relationships to the other Malaysian primates based on Cyt $b$ gene sequences. J Wildlife Parks 26: 119128.

Md-Zain BM, Abid-Kamal SNA, Aifat NR, Abdul-Latiff MAB, MohdHashim A, Ampeng A, Yaakop S, Samat A. 2018a. Molecular identification of shark fins in Malaysian Borneo's local markets. Biodiversitas 19: 1035-1043. 
Md-Zain BM, Abdul-Mutalib SA, Aifat NR, Masstor NH, Mohd-Yusof NS, Mohd-Hashim A, Abdul-Latiff MAB, Yaakop S, Samat A 2018b. Molecular phylogenetic inference of White-Spotted Guitarfish (Rhynchobatus australiae) collected from local Malaysian fish markets. Biodiversitas 19: 1382-1386.

Mohd-Yusof NS, Nik-Rashidi NAR, Zulkifli NA, Yaakop S, Hazmi IR, Md-Zain BM. 2018. Phylogenetic relationships of Heterotrigona itama in Malaysia based on COI DNA sequences. Serangga 23: 3648.

Munds RA, Nekaris KAI, Ford SM. 2013. Taxonomy of the Bornean Slow Loris, with new species Nycticebus kayan (Primates, Lorisidae). Amer J Primatol 75: 46-56.

Nekaris, KAI, Nijman V. 2007. CITES proposal highlights rarity of Asian nocturnal primates (Lorisidae: Nycticebus). Folia Primatologica 78: 211.

Nekaris KAI, Blackham GV, Nijman V. 2008. Conservation implications of low encounter rates of five nocturnal primate species (Nycticebus spp.) in Asia. Biodiv Conserv 17: 733-747.

Nekaris KAI, Starr CR. 2015. Conservation and ecology of the neglected slow loris: priorities and prospects. Endangered Species Res 28: 87 95.

Ni Q, He X, Xie M, Zhang M, Xu H, Yao Y, Li Y, Yang J. 2016 Complete mitochondrial genome sequence for the Nycticebus pygmaeus (Primates, Lorisidae). Conserv Genet Resour 8:235-237.

Nur-Syuhada N, Magintan D, Siti-Hajar AR, Aisah MS, Nor MS. 2016 The wildlife research \& rescue programme for mammals at Hulu Terengganu Hydroelectric Project (HTHEP), Terengganu, Peninsular Malaysia. AIP Conf Proc 1784: 060036. DOI: 10.1063/1.4966874.

Ridley HN. 1900. On the use of the slow loris in Malay medicine. J Straits Branch Royal Asiatic Soc 34: 31-34.

Roos C, Boonratana R, Supriatna J, Fellowes JR, Groves CP, Nash SD Rylands AB, Mittermeier RA. 2014. An updated taxonomy and conservation status review of Asian primates. Asian Primates J 4: 2 38 .

Rosli MK, Zakaria SS, Syed-Shabthar SMF, Zainal ZZ, Nor MS, Mahan MC, Abas-Mazni O, Md-Zain BM. 2011. Phylogenetic relationships of Malayan gaur with other species of the genus Bos based on cytochrome $b$ gene DNA sequences. Genet Mol Res 10 (1): 482-493.

Rovie-Ryan JJ, Gani M, Gan HM, Bolongon GG, Cheng TC, Razak N, Rosli N, Aziz MA, Matkasim K. 2018. Rediscovery of Nycticebus coucang insularis Robinson, 1917 (Primates: Lorisidae) at Tioman Island and its mitochondrial genetic assessment. Sains Malaysiana 47 (10): 2533-2542.

Somura H, Hori H, Manome Y. 2012. Sequence analysis of mitochondrial DNAs of 12S rRNA, 16S rRNA, and cytochrome oxidase subunit 1 (COI) regions in slow lorises (Genus Nycticebus) may contribute to improved identification of confiscated specimens. ISRN Zool 2012: 498731. DOI: 10.5402/2012/498731.

Somura H, Hori H, Manome Y. 2013. Nycticebus bengalensis mitochondrion, complete genome. https://www.ebi.ac.uk/ena/data/view/KC977312.

Starr C, Nekaris KAI, Streicher U, Leung L. 2010. Traditional use of slow lorises Nycticebus bengalensis and N. pygmaeus in Cambodia: an impediment to their conservation. Endangered Species Res 12:17-23.

Streicher U, Singh M, Timmins RJ, Brockelman W. 2008. Nycticebus bengalensis. The IUCN Red List of Threatened Species 2008: e.T39758A10263081. 10.2305/IUCN.UK.2008.RLTS.T39758A10263081.en.

Swofford DL. 2002. PAUP*: Phylogenetic analysis using parsimony. v. 4.0 b10. Sinauer Associates, Sunderland, MA.

Syed-Shabthar SMF, Rosli MKA, Mohd-Zin NAA, Romaino SMN, Fazly-Ann ZA, Mahani MC, Abas-Mazni O, Zainuddin R, Yaakop S, Md-Zain BM. 2013. The molecular phylogenetic signature of Bali cattle revealed by maternal and paternal markers. Mol Biol Rep 40: 5165-5176

Takacs Z, Morales JC, Geissmann T, Melnick DJ. 2005. A complete species-level phylogeny of the Hylobatidae based on mitochondrial ND3-ND4 gene sequences. Mol Phylogenet Evol 36: 456-467.

Thach HM, Le MD, Vũ NB, Panariello A, Sethi G, Sterling EJ, Blair ME 2018. Slow loris trade in Vietnam: Exploring diverse knowledge and values. Folia Primatologica 89: 45-62. 